\title{
Population, Resources, and Environment: Implications of Human Behavioral Ecology for Conservation
}

\author{
Bobbi S. Low \\ Joel T. Heinen \\ University of Michigan
}

\author{
"Had we but world enough, and time, \\ This coyness, lady, were no crime." \\ Andrew Marvell, "To His Coy Mistress"
}

It was certainly no accident that Repetto (1986) titled his essay on conservation management problems World Enough and Time, after Marvell's lament to his mistress. Today we face global problems of environmental degradation and extinction that have reached unprecedented proportions, and time grows ever shorter. Brown $(1990 ; 1991)$ suggests that we are witnessing an "illusion of progress": progress because on the surface, many of the traditional scourges of mankind are diminishing. We are feeding more people and increasing standards of living in many places, and we have lived through the longest span of economic growth in history. This progress is an illusion, Brown argues, because there are high prices attached to the good fortune: destruction of nonrenewable resources and rainforests (e.g., Hecht \& Cockburn, 1990), desertification (Chiras, 1988; Revelle \& Revelle, 1988), increased pest outbreaks and pollution from increased use of pesticides, fertilizers, and artificial irrigation systems (Re-

Please address correspondence to Dr. Low, Evolution and Human Behavior Program, School of Natural Resources, University of Michigan, Ann Arbor, MI 48109.

Population and Environment: A Journal of Interdisciplinary Studies

Volume 15, Number 1, September 1993

(C) 1993 Human Sciences Press, Inc. 
velle \& Revelle, 1988), resource scarcity for much of humanity (Smith, 1982), global warming (Edgerton, 1991). It is likely that thousands of species will be extirpated before they are even described (Myers, 1984; Wilson, 1988). Locally, landfills are being closed because they are simply too full. We protest against the dumping of nuclear wastes as we use the power from nuclear plants.

Conventional wisdoms exist about the way humans used resources in the past, and our strategies to promote conservation in the face of devastating global problems are in part based on these wisdoms. If they are wrong, our strategies will not work. These conventional wisdoms include our perception that people in preindustrial ("traditional") societies, being more directly and immediately dependent on the ecology of the natural systems around them, were more conserving and respectful of those resources (e.g., Bodley, 1990; but see Hames, 1991). Thus, as we have developed technological insulation against ecological fluctuations, we feel we have, in important ways, "lost touch" with ecological realities and constraints, and have, to some degree, lost our respect for them. We also commonly think of ourselves, as ethical individuals, giving value to the common good; thus, because none of us wishes to cause destruction of resources, each of us will accept some level of personal cost to ensure the common good.

If these conventional wisdoms were true, simple information about the effects of our actions would be sufficient to solve ecological problems, as individuals accept costs for the common good. It should be relatively easy to get each of us to accept some small cost for the good of all. Conventional wisdoms generate normative prescriptions: that we should all become more reverent, that we need more information about the impact of our actions on ecological balances. Yet today we seem trapped, with repeated examples of cases in which we all agree that we need certain solutions, though we are unable to make ourselves accept the cost: for example, safe storage for hazardous wastes (but "not in my back yard"), avoidance of highly toxic chemicals (yet years after DDT was banned in the US, we allowed its production-and accompanying profit-for export), more recycling as our landfills overflow (yet, in the US we recycle only about $13 \%$ of solid wastes, and as we show later, most of that is material for which we get refunds).

What is wrong? This litany of environmental problems could be expanded; that is not our purpose. We can see that our current efforts are discouragingly minimal in their effects. We need a new paradigm. The examples above, for all their variability in scope, particulars, involvement of lesser-developed countries (LDCs) or developed countries (DCs), all 
BOBBI S. LOW AND JOEL T. HEINEN

have in common an underlying theme, and are all predictable from a behavioral ecological approach to human resource use.

Here we examine human resource use in a behavioral ecological context, generating testable predictions about resource use patterns. As we explain in the next section, a behavioral ecological approach argues that humans, like all other living organisms, evolved to get resources in order to survive and reproduce, and that individual and familial wellbeing has always been central, while the good of the group has seldom been relevant. We argue that natural selection has shaped all living organisms to exploit resources effectively, in competition with each other, and that our problem is that through our cleverness, we have created a novel evolutionary circumstance-we have such technology that the very behaviors we evolved to perform are those likely to ruin us. We have evolved, we will argue, to maximize short-term rewards that have, in our history, correlated with reproductive success. Now these strategies may be harmful, not helpful. If we could simply set aside our evolutionary past, perhaps we could easily act as if the earth were our family, regardless of personal rewards. But that seems to be difficult (see Hawkes \& Charnov, 1988), and today in developed countries we have enormous technology for resource exploitation and high proximate rewards for achieving status and power, giving us an ability to cause massive extinctions, deforestation, and global warming. Even the crucial problem of overpopulation (e.g., Ehrlich \& Ehrlich, 1990) arises from individuals satisfying proximate desires. We literally can destroy the earth to satisfy our proximate goals.

If we evolved, like all other living things, to be genotypically selfish, to strive for resources for ourselves and our kin, then we have evolved to apply our considerable intelligence to do just that, and Devil take the hindmost. When technology was sufficiently limited, the results were as for other species: occasional population explosions, occasional resource constrictions, occasional local extinctions. We have reached a state in which our population density and developed technology mean that we can cause our own global extinction. We have not evolved to consider the global population our family. This is the problem Boulding (1977) tackled when he spoke of the difficulties and complexities of building a "public"-a large group willing to bear individual costs for a common good.

\section{A BEHAVIORAL ECOLOGICAL APPROACH}

If human resource use has followed the same behavioral ecological rules as other species, people are unlikely to give up short-term individual 
or familial benefits for long-term societal or global gains, and this is likely to have been true throughout our history as a species, rather than a new phenomenon associated with technological innovation. This prediction is in striking contrast to the conventional wisdoms.

We know a great deal about the evolution and ecology of resource use in other species: the costs and benefits; the influence of environmental extremeness, predictability, and patchiness, the evolution of sex differences (e.g., Dawkins, 1976, 1982, 1986; Dewsbury, 1978; Wittenberger, 1981; Daly \& Wilson, 1983; Alcock, 1984; Trivers, 1985; Krebs \& Davies, 1991; and specific studies cited therein). The organisms we see today are the descendants of those that most successfully survived and reproduced in past environments. Strategies for survival and reproduction are all-important, though their appropriate analysis may be complicated. This simple logic, first employed explicitly by Darwin $(1859,1871)$, gives rise to complex and profound effects. Although only heritable variation is important, with complex social animals there can be significant cultural heritability, and interaction between cultural and genetic transmission can certainly complicate analysis (Cavalli-Sforza \& Feldman, 1981; Lumsden \& Wilson, 1981; Boyd \& Richerson, 1986; Dawkins, 1986).

In this large body of theory and empirical data, two things stand out: [1] genetically selfish behaviors, those which enhance an individual's reproduction, are always favored; and [2] fertility responds to the richness, controllability and predictability of important resources, and to the sources of juvenile mortality. All living things have evolved to acquire and use resources to survive and reproduce. The ways they do so are constrained by ecological conditions; the most effective and efficient resource strategies in any particular environment are those that tend to prevail over time. Ceteris paribus, those individuals using efficient strategies leave more offspring in the next generation than their competitors.

Not immediately apparent is that successful reproduction does not necessarily mean producing the most offspring, or even the most surviving offspring. Even for relatively nonsocial animals, success is seldom achieved by the strategy "eat and reproduce all you can." In nonhuman species, for example, infanticide, lethal conflict, delayed reproduction, sterility (e.g., nonreproductive helpers at the nest, Woolfenden \& Fitzpatrick, 1984; sterile honeybee workers, Seeley, 1985; infanticide, Hausfater \& Hrdy, 1984) are all phenomenia that at first glance look as though they decrease, rather than increase, reproductive success-but further analysis makes it clear that, except for rare pathologies, these behaviors are found in specific ecological and social circumstances, and that 
BOBBI S. LOW AND JOEL T. HEINEN

their impact is increased lineage success. Each individual has reproductive interests, but these interests are shared by other individuals who share common genes-genes identical by descent-and thus several avenues are open to enhance net reproductive success (inclusive fitness maximization, Hamilton, 1964). We expect organisms, including humans, to engage in activities that benefit relatives; the extent to which this is true will depend on the degree of relatedness. Thus helping relatives, even at some cost to oneself, can be genetically profitable.

Individuals (and their genetic lines) can also prosper through reciprocity-cooperation (Trivers, 1971). Cooperation can be a highly effective competitive strategy. Again, producing the maximum physiologically possible number of offspring is not always the best reproductive strategy. Humphrey $(1983)$ and Alexander $(1971 ; 1979 ; 1987)$ argue that even our powerful human intelligence probably evolved in the context of resource and mate competition. Reciprocity occurs only in long-lived, social species-species in which individuals recognize each other and are likely to interact repeatedly. Organisms in long-lived social species, including humans, are likely to do things which benefit potential reciprocators without immediate profit, because there is some probability that there will be future interactions between/among the individuals (indirect reciprocity). If individuals interact only rarely or occasionally, indirect reciprocity is extremely vulnerable to invasion by cheating, and individuals will mirror the behavior of others in a "tit-for-tat" manner (l'll start by cooperating, but if you default, I will, too; see Axelrod \& Hamilton, 1981). When risks are high, helping behaviors are likely to occur only or primarily among kin.

The relevance of these patterns to resource problems (e.g., "not in my back yard") should be immediately obvious. It is easy to say strategies should be followed, but only if our individual cost is low, or if we see an immediate benefit-to ourselves - will we be likely actually to do what we say is important. Many behaviors that we call in ordinary parlance "altruistic $^{\prime \prime}$ have evolved because they were likely to benefit the inclusive fitness of those who did them. Alexander (1974) separated these behaviors in a clear fashion; it is obvious that genotypically altruistic behaviors, which benefit reproductive competitors at a reproductive cost to the doer, cannot evolve through natural selection. While they may occur, they are always vulnerable to competition from genotypically selfish (lineage-enhancing) behaviors (Table 1). Thus true genotypic altruism, paying a real individual and familial cost for the sake of nonrelatives, will remain rare. Only if selection worked to favor the group, rather than genetic lineages, would genetic altruism be common. 
TABLE 1

Categorization of the Impacts of Behaviors on Phenotypic and Genotypic Condition (Modified from Alexander 1974).

\begin{tabular}{|c|c|c|}
\hline $\begin{array}{l}\text { Phenotypic } \\
\text { Effect }\end{array}$ & $\begin{array}{c}\text { Genotypic } \\
\text { Effect }\end{array}$ & Examples \\
\hline $\begin{array}{l}\text { Profitable } \\
\text { ("selfish") }\end{array}$ & $\begin{array}{l}\text { Profitable } \\
\text { ("selfish") }\end{array}$ & numerous; all overt competition \\
\hline \multirow[t]{3}{*}{$\begin{array}{l}\text { Costly } \\
\text { ("altruistic") }\end{array}$} & $\begin{array}{l}\text { Profitable } \\
\text { ("selfish") }\end{array}$ & parenting, nepotism, reciprocity \\
\hline & & $\begin{array}{l}\text { Because Natural Selection Favors Only Ge- } \\
\text { notypically Profitable Behaviors, Under Natural }\end{array}$ \\
\hline & & $\begin{array}{l}\text { Selection, Behaviors Above the Line Should Be } \\
\text { Common; Below the Line, Rare }\end{array}$ \\
\hline $\begin{array}{l}\text { Profitable } \\
\text { ("selfish") }\end{array}$ & $\begin{array}{l}\text { Costly } \\
\text { ("altruistic") }\end{array}$ & $\begin{array}{l}\text { ?? Perhaps a rich miser who disinherits his family, } \\
\text { leaving an anonymous gift to a home for unwed } \\
\text { mothers }\end{array}$ \\
\hline $\begin{array}{l}\text { Costly } \\
\text { ("altruistic") }\end{array}$ & $\begin{array}{l}\text { Costly } \\
\text { ("altruistic") }\end{array}$ & Mother Theresa \\
\hline
\end{tabular}

In light of this evolutionary background, it should not be surprising that ecological conditions change the costs and benefits of helping. For example, Minnis (1985, p. 38), in a discussion of preindustrial societies, notes that as food stress increases, sharing of food increases to a point, and then decreases. In really extreme cases, dependent kin (children) can be abandoned (e.g., Boswell, 1988; Turnbull, 1972). Even in good times, sharing, as we would predict, is not random; it tends to be directed toward $\mathrm{kin}$, and toward individuals from whom the giver might hope to receive benefits (Hill \& Kaplan, 1988a; Chagnon, 1982; Turke \& Betzig, 1986).

\section{Levels of Selection and Conservation Issues}

To conservationists, the most familiar "levels of selection" problem is probably that of the commons (e.g., Hardin, 1968). These are resources to which all have access (and which, if destroyed, will hurt all), but which give short-term profit to individuals when used exploitatively. Typically, when many unrelated individuals simultaneously have access to resources, whether the resources are grazing lands or whale populations, they tend to 
BOBBI S. LOW AND JOEL T. HEINEN

exploit the resource more than is wise from the community's long-term prospective, in order to gain personally.

Such problems should be rare if our conventional wisdoms were correct, and we all felt our interests were identical to those of humans as a group-if selection were most potent at the level of the group. For example, Wynne-Edwards (1962) and others hoped to find the answer to limited population fluctuations of many species in terms of group benefit. He argued that individuals behaved in ways that, while costing each individual reproductively, helped maintain the population below the carrying capacity, thus allowing the population to persist through time (true genetic altruism in Table 1).

Such an approach has a serious failing. Selection cannot favor individuals who act for the benefit of a group of nonrelatives at the expense of their own inclusive fitness. Situations in which the costs are paid by individuals other than those gaining the rewards are unstable. Yet this does not mean that we are simply harsh and fierce competitors, with no redeeming features. First, and importantly, helping our family and friends, favored by individual-level selection, is common (phenotypically altruistic, genotypically selfish behaviors in Table 1). Sometimes, too, the group may appear to benefit as a result of the cumulative selection on individuals (e.g., Williams, 1966) even though natural selection has acted on the level of the individual. Interestingly, Wynne-Edwards (1962) argued that all species except humans were group-selected, because human populations seemed not to be "regulated." He said this because even when he was writing, the conflicts between individual profit and group good were already clear. In fact, humans alone may show any evidence of group selection at all (laws, for example, are inflictions of constraint on individual behavior by coalitions of others in the group; Alexander, 1987).

Although research for some decades now has produced no evidence that any organism has evolved to assist unrelated individuals while costing the doer, this is not to say such altruistic behaviors will never occur; it is just that because they cannot spread by natural selection they will be rare. Mother Teresa, Mahatma Gandhi, and the Dalai Lama are/were certainly altruistic by any standards. All are noteworthy in part because,they are rare exemplars. The obvious outcome to genotypic altruism (Table 1) is that the genetic altruists decline in the population, being steadily replaced by individuals who behave to their own reproductive benefit. Of the great religious leaders mentioned above, only one (the Mahatma) left any known descendents. Darwin $(1859$, p. 260$)$ himself recognized the problem of altruism when he stated "if it could be proved that any species does some- 
POPULATION AND ENVIRONMENT

thing for the sole good of another species, my theory is annihilated, for such could not have evolved by natural selection."

This particular result of natural selection is absolutely key to understanding human resource use. When we urge, as in the 1970s environmental movement, that we should all pay an immediate, relatively small cost (e.g., taking shorter showers, taking the trouble to recycle materials), in the interests of gaining long-term global benefits, involving nonrelatives and competitors, we are asking for behaviors that have no evolutionary precedent, and could only have arisen through group selection. The result? Countless proximate reasons why "it's too much trouble," why "my part won't make any difference," and burn-out from those who do undertake the short-term costs. In part, we have made mistakes in our scenario-building. If we forecast utter doom by some date, we run the risk of people imagining it, but then finding, when the time comes, that things are bearable-when that happens, the next gloomy scenario is less potent. And all of this complicates the fact that making things "bearable" may involve real short-term exploitation, combined with externalization of costs, and this cannot be done forever.

Asking for altruism just has not worked as a widespread strategy. We suggest that when short-term gains accompany short-term individual costs, results beneficial to the group (e.g., long-term reduction in resource consumption) are more likely.

\section{Novel Evolutionary Environments}

In other species and in preindustrial human societies for which we have sufficient data, individuals who have more resources typically have greater reproductive success. Now, however, we may have broken the link between resource accumulation and inclusive fitness (Figure 1). If we evolved, like other organisms, to strive for resources, using them for ourselves and our families, one powerful corollary is that we typically derive proximate rewards of satisfaction and pleasure from that struggle. What we perceive has always been some proximate cue like pleasure or pride, although the reason the behavior persists or dies out is its effect on inclusive fitness. Whenever some behavior has an evolutionary history of reproductive advantage, and conditions change ("novel evolutionary events"), there is a possibility for that behavior to continue being driven by proximate cues that in the past correlated with reproductive advantage, even when the proximate cues are currently unhinged from that funcitonal advantage. We argue that humans are in precisely this situation with regard to the use and conservation of resources (Figure $1 \mathrm{~b}$ ). 
BOBBI S. LOW AND JOEL T. HEINEN

FIGURE 1. The role of proximate and ultimate processes in behavior [a] in ordinary selective environments; [b] in novel evolutionary environments. While ultimate reproductive impacts actually drive the striving (arrows), organisms respond to proximate cues (closed loop). Thus, in novel evolutionary environments, if the link between proximate cues and ultimate reproductive gain is lost, the organism may persist in behaviors no longer reproductively profitable.

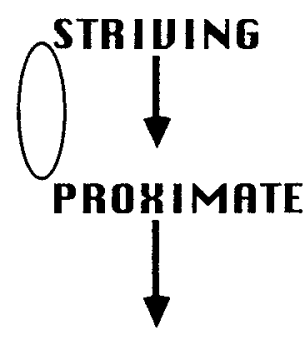

ULTIMATE

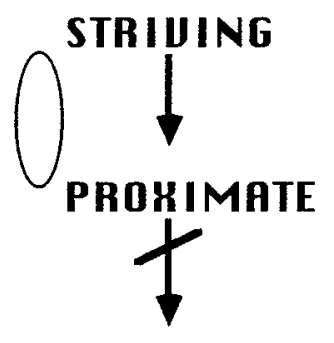

ULTIMATE

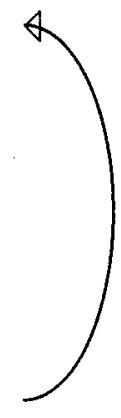

A. Under natural selection
B. In novel evolutionary environments

There are many cases of novel evolutionary events influencing the behavior and demography of animals. For example, Great Tits in Great Britain began to feed out of (evolutionarily novel) milk bottles although their probing behaviors evolved to forage on bark and twigs (Krebs \& Davies, 1981); a male chimp in a well-studied group gained status by banging empty metal containers together instead of the more traditional branches (Goodall, 1986); and gulls which evolved as generalist feeders showed marked increases in population density as a result of more garbage dumps on the east coast of the United States (Kadlec \& Drury, 1968; 
Drury, 1973), while other seabirds declined in abundance due to gull predation (Podolsky 1985). In fact, the most frequent reason that animals become rare or endangered is that their habitat is altered by humans (Ehrlich \& Ehrlich, 1981).

Because no organism, including humans, has evolved to be aware of ultimate selective effect, but only of proximate cues, selection acts so that those things which enhance our survivorship or reproduction-forming friendships, having sex-tend to be perceived as pleasurable, and acts which typically detract from our survivorship or reproduction-getting burned-are perceived as unpleasant or painful. Consider a simple example of how novelty complicates this process. In nature, sweet foods are seldom harmful, and sour and bitter tastes are often correlated with the presence of harmful alkaloids. Thus a preference for sweet tastes became widespread in omnivores, including humans. In natural situations, it was difficult to obtain sufficient sugar without other nutrients and fiber, to create problems of obesity. Once we humans invented technologies for refining and concentrating sugar, we created foods that had enormous concentrations of sugar, breaking the selective link between sweet taste, the proximate cue, and good food source, which results in enhanced survivorship and reproduction. But proximate cues drive the system, and selection, as a passive sieve, operates. So, we retain a preference for sweet taste that is often currently counter-adaptive (health risks, and perhaps sexual selection). As noted above, we think humans are in precisely the same situation with regard to the use and conservation of resources (Figure 1).

\section{NATURAL SELECTION AND HUMAN RESOURCE USE}

A behavioral ecological approach makes several predictions about resource use, fertility, mortality, male-female differences, and about how those are predicted to differ in various environments. We do not argue that particular genes force particular behaviors, and we assume learning is important. A variety of proximate mechanisms might mediate any particular pattern. We simply ask: Under the described environmental conditions, what strategies will be favored (will result in enhanced lineage success) compared to alternate strategies? What patterns would we predict as a result of specific environmental conditions?

Ideally, of course, we would like to assemble here a series of tightly controlled statistical tests; however, some of these predictions are sufficiently new that data have not been systematically gathered. Part of our purpose here, in fact, is to urge data collection to test these predictions. 
BOBBI S. LOW AND JOEL T. HEINEN

Here, we [1] examine data from several literatures: cross-cultural, ecological, historical, demographic and economic; and [2] review both systematic and simple descriptive data bearing on the hypotheses. We hope to bring together the clues that will allow us to falsify these predictions, or to suggest the kinds of data we need.

\section{Prediction [1] Resource Types Conservatively Used}

If enhancement of individual and familial survival and reproduction is the trait favored by natural selection, in traditional societies, resources will be most conservatively used when there is rapid and clear feedback regarding the impact on family and individual welfare (when overexploitation carries clear individual and familial costs).

Under some conditions, human resource use does not result in resource degradation. Evolutionary theory predicts that these conditions would include [1] exclusive management by small groups of relatives and neighbors likely to interact for long periods of time, and [2] resource types with feedback that allows people to assess what rates of harvest may be unsustainable. People in such cases have individual incentives, through kin selection and reciprocity, to manage resources conservatively, and they have the information to see how their use affects the resource. They are likely to have resource-use rules, and punish cheaters (see Ostrom, 1990).

Small groups of people cooperatively manage Amazonian fisheries; such small communities, which are typically made up of relatives and neighbors likely to interact over long periods of time, with exclusive or near exclusive access to the resource, provide an exception to Hardin's "tragedy of the commons." Chapman (1989) discussed the exploitation of Amazonian fisheries in the political context of changing relations of common and private property resources. She contended that political ideologies favoring large-scale development and use caused decline of the fisheries through the lack of local control. She argued that this was related to variations in the "GINl" coefficient (a measure of inequality in wealth, Murdock, 1980; Smith, 1982). Similarly, Bunker (1985) contended that extractive economies have led to the enrichment of dominant classes at the expense of the poor, and to the depletion of timber and other Amazonian resources. Wealth inequalities do seem to be an important concomitant of overexploitation; if humans strive to acquire resources to enhance reproductive success, overexploitation can result as a side effect. In interacting groups of kin with exclusive or near-exclusive use of a resource, overexploitation should be less likely, and sustained harvest may be the best reproductive strategy. 
POPULATION AND ENVIRONMENT

If control of local resources is removed, it may be in individuals' interests to increase exploitation (cf. Dove, 1988; Ostrom, 1990). It is an emerging paradigm in the international development literature that the most effective management strategy for some natural resources (e.g., tropical forests) may be to turn at least some control over to local communities (e.g., Pragtong \& Thomas, 1990; Peluso et al., 1990). The Nepalese Government is addressing this to some extent with the Annapurna Conservation Area Project, a new kind of protected area for the country, which includes a great deal of local participation regarding the use and conservation of resources in the heavily visited Annapurna region of central Nepal (Hough \& Sherpa, 1989). Local control is not a panacea, and external markets are important; in another area of the Himalayas, Moench (1989) reported that even purely local consumption of forest products in traditionally-managed areas can lead to resource degradation, albeit at a much slower rate than if all local controls are removed. All of Nepal's existing parks and reserves have management conflicts with local people to some extent (Heinen and Kattel, 1992). We predict that the more local the control within different zones of the reserve, the more sustainable will be the management strategy.

Overexploitation is common when local people are marginalized and have no immediate incentive to conserve (e.g., Harrison 1987; Shaw 1989). McNeely (1988), in a new and provocative view of economics and conservation, proposed that various kinds of incentives and disincentives implemented at the local level are needed to sustain conservation activities in protected areas. Young (1991), Daly and Cobb (1989), and Crowfoot and Wondolleck (1990) all contend that incentives are needed by all parties to assure participation in environmental dispute settlements. Although these authors do not address the issue directly, their conclusions are similar to ours: People respond most readily to immediate costs and benefits. We argue that they do so ultimately because those are the types of rewards which led to greater reproductive success throughout our evolutionary history.

These examples all involve relatively homogeneous, stable, local communities, often comprising several kin groups and with a preference for cousin marriages, in which people are essentially involved in subsistence use of local resources. In these cases, the exploitation of resources for economic profit was initiated by outsiders-central government, foreign investors. In contrast, local control by non-relatives in market economies, with highly developed transportation, may not result in the most conserving use: We have only to think of the old-growth forest in Oregon, or conflict over salmon management and forestry in the Pacific Northwest. In 
BOBBI S. LOW AND JOEL T. HEINEN

these cases, local individuals may find the "get mine and get out" strategy all too tempting. If property rights and market economies allow, some individuals may be able to "corner the market," gaining control over the resource, then regulating prices to maximize profit. When this is so, coalitions of others, working through central government agencies, can have a moderating influence; but conflicts persist.

If conservation benefits can be made to outweigh costs for people through a system of incentives which confer immediate or short-term benefits to people and their families, conservation strategies will succeed; if not, we argue, they will more often fail. Examples of local incentives in the case of protected areas include the sustained removal of some forest products, or providing employment to villagers. In a similar vein, Repetto (1986) suggested promoting conservation strategies that have proven effective, mostly by providing benefits to local people (e.g., improved health care and lowered infant mortality rates). Other recent volumes on economics and conservation which address the general problem of economic valuation of biotic resources are: Prescott-Allen and Prescott-Allen (1987), Oldfield (1989), and Dixon and Sherman (1990). These approaches may prove important for justifying conservation activities to policy makers, but we suspect the activities can only persist with systems of incentives and/or benefits to local people such as those discussed by Repetto and McNeely. Such systems would approximate the ultimate, evolutionary reward systems of human hunter-gatherer societies throughout most of our history. Pearson (1985) contended that many multinational corporations are implementing new policies in LDCs which involve moving away from direct ownership of natural resources, and toward contractual relations with locally-owned and managed businesses, with the rationale that this will increase profits over the long term.

\section{Prediction [2] Resource Destruction in Pre-Industrial Societies}

Deliberate overexploitation in traditional societies is likely when [a] it yields individual genetic profit (and/or its proximate cues, status or wealth enhancement), and [b] technology is sufficient to accomplish overexploitation. Thus the impact of introduction of more efficient technologies will vary, depending on whether their use will result in greater (short-term) individual and familial benefit.

Exceptions to the conventional wisdoms about preindustrial societies' resource-use patterns are common. When do they occur? Humans can cause destruction or extinction in a variety of ways. They may do so directly, as in hunting a species to extinction (e.g., moas in New Zealand). 
Deliberate exploitation is predicted to cause extinction or environmental degradation most often when technology is sufficient, individual payoffs exist, and feedback on human impact is slow. Throughout most of our evolutionary history, these conditions were seldom met, although humans have apparently always modified their environment--.even hunter-gatherers deliberately changed the environment by burning, for example, and there is evidence that tribal people are capable of over-hunting (Clay, 1988; Bodley, 1990). Typically, however, the technology was not widespread, and had principally local and limited environmental impacts (but see Lowdermilk, 1953). Thus, widespread concern about a conservation ethic is more or less a twentieth-century phenomenon (e.g., Spoehr, 1956; Hargrove, 1988; Strong, 1988; Callicott, 1989).

In addition to deliberate exploitation, humans may also introduce crop plants or domestic stock, or inadvertent "weeds" or animal pests (e.g., rats). Exploitation is most likely to be directly related to individual striving, while introductions result more often from a lack of information. From the Quarternary, documented extinctions have occurred as a direct result of human activity (Martin, 1984). On the Hawaiian Islands, $54 \%$ of endemic birds went extinct due to activities of early Polynesians (Olson \& James, 1984), and the same case, better-or-worse documented, can be made for most other continents or islands (Martin, 1984).

Diamond (1984) analyzed factors associated with resource destruction and human activity. "Man's arsenal" included weaponry, stock, pigs, dogs, swift predators like cats, agriculture. All of these were usually deliberately brought. Rats often accompanied humans inadvertently. Faunal susceptibility was an independent consideration, arising from fire risk, absence of native swift predators, rats and land crabs, and previous absence of humans. Of the four prehistoric extinction waves definitely attributable to man, three "resemble what literate Europeans have been doing on numerous oceanic islands" (Diamond, 1984, p. 852). Patterns of particular extinctions varied. In Pleistocene North America, human-caused extinctions included large mammals, few small mammals, and some relatively large birds.

Though less well known, the late Pleistocene extinctions in South America and Australia followed much the same pattern. In New Zealand, the Polynesian settlement extinguished all of the giant flightless birds, local populations of marine mammals, numerous species of both small and large flightless and flying birds, frogs, lizards, and flightless insects (Anderson, 1984; Cassels, 1984; Trotter \& McCulloch, 1984), as well as numerous plant species (Crosby, 1986). Only part of the pattern is attributable to weaponry and hunting, which might be seen as more relevant to human 
BOBBI S. LOW AND JOEL T. HEINEN

intent. Other impacts arose from introduced stock, predators, and plant species, and unwanted commensals like rats. The situation is further complicated by incomplete information on extinctions, and variability in faunal resistance (Diamond, 1984). Current work suggests that the abandonment of Mayan cities was related to agricultural failures (Deevey et al., 1979; Turner, 1982). Ancient Sri Lankans, by forest clearing on mountainous regions, created flooding and reservoir siltation (Lowdermilk, 1953), causing serious problems.

Both technological sufficiency and profit are important. In North America, Great Lakes Indian societies had sufficient technology to have great impact on beaver populations; nonetheless, these populations remained relatively stable until the Hudson's Bay Company entered the area, introducing a market economy, and made extra beaver pelts useful. A male beaver pelt, according to company records (Albany Fort, 1773), was worth a brass kettle, or twenty steel fishhooks, or two pounds of Brazilian tobacco (Newman, 1989, p. 60). In this case, the technology was sufficient for some time without resulting overexploitation; what was lacking was immediate advantage to continued intense hunting.

Plains Indians who hunted bison were, regardless of the hunting technique, highly selective in their use of meat, hides, and other by-products of the hunt (Haines, 1970; Speth, 1983), seeking particularly fat and fatty meat, and leaving heavy, less nutritious parts at the kill. When cliff jumps were used, the hunt could become inefficient in terms of the amount of the kill actually used. Cliff jumps produced far more bison meat for less effort than competing technologies, but were certainly inefficient, and hardly "conserving" in that storage and preservation techniques were inadequate. Huge amounts of meat rotted at the base of cliffs; hunters took only the choicest meat. In this case, certain technologies were more than adequate; others lagged behind.

Hames $(1979,1989)$ found that among the Ye'kwana, enhanced technology increased hunting efficiency, but did not increase exploitation. Game could neither be stored nor traded in a market economy; its availability did not lead to feast and famine conditions. Thus, already efficient hunters simply had more spare time. When such time is used in male-male bonding and negotiations, it may constitute politics, and may indeed have some reproductive payoff for individuals (e.g., Hames, 1979; Chagnon, 1988; Low, 1990a). On the other hand, when steel axes were introduced in New Guinea, with a market available (Salisbury, 1962), serious ecological degradation followed.

One might think that normative beliefs would strongly affect these patterns. Religious beliefs can be an important proximate cause of conserva- 
tion, although we argue they are unlikely to be very effective if no individual or familial benefits accrue. In all major religions it is considered noble and just to aspire to poverty or limited resource use of some form (e.g., Durning, 1991). In many Asian religions there is a great reverence and respect for nature (Callicott \& Ames, 1989). The evidence suggests that humans the world over behave in a genotypically selfish manner, sometimes in accord with their religious inculcation, sometimes in spite of it (cf. Callicott \& Ames, 1989). Although cultural and religious beliefs about important affairs may well have considerable inertia, making them slow to change, sometimes as slow as genetic algorithms, when environmental conditions change, religious beliefs can sometimes be altered rather quickly.

We suspect that protective religious reverence for nature is more strongly practiced when kinship structures are strong and families benefit from conservative management, and further, that conservation philosophies relying on generalized and diffuse group benefits (e.g., Lovelock, 1979; Devall \& Sessions, 1985; Taylor, 1986) are probably doomed to failure in the absence of individual or kinship benefits to conservative management. We would be delighted to be wrong but suspect we are not. In most hunting and gathering societies, while religious activities may surround hunting, men who are good hunters can get more wives, and men's attitudes about hunting (and various achievements) center on how hunting skill helps their social and reproductive success (e.g., Chagnon, 1988; Low 1990a, 1992).

Thus, two conditions apparently must exist for active rather than incidental environmental degradation to occur: The technology must be sufficient to accomplish it, and there must be some reward to individuals who, for example, hunt or clear land at destructive levels. If, in addition, the size of the resource pool is unknown or feedback is slow (e.g., whaling, sealing), overexploitation is even more likely.

\section{Prediction [3] Information and Resource Destruction in the Industrial World}

Indirect or incidental damage, as through habitat destruction, is most likely when information or feedback about the resource is limited. Even when we move from considering traditional societies to modern industrial conditions, those resources most likely to be over-exploited should be those with slow feedback cycles-those on which it is hard to see the impact of resource use. This is especially critical for resources in which the size of the resource pool is difficult to measure and there are 
BOBBI S. LOW AND JOEL T. HEINEN

many potential users: many non-renewable resources like coal, oil, gas, and pleistocene water deposits, and renewable resources like whales and large secretive terrestrial mammals (e.g., many fur-bearers). The most profitable individual strategy is "get mine and get out."

Humans, like other organisms, evolved to use resources primarily for individual gain, even when this generates incidental expenses for the group. Sometimes the costs to the group as a whole, or to those receiving no profit from the resource use, can be dramatic. Our high rate of fossil fuel consumption is causing unprecedented pollution problems which contribute to increasing atmospheric $\mathrm{CO}_{2}$ and possibly to global warming (Mintzer, 1987; Renner, 1989), and a series of public health concerns (Ogden \& Williams, 1989). Gaps in the supply of these fuels raise serious concerns for global security (Anonymous 1985). The United States recently concluded a ground war in the Persian Gulf, yet the 1991 energy proposal from the Bush Administration made no concessions for decreasing foreign oil dependence or increasing gas mileage, and few for research and development of alternative fuels. Despite initial concerns about the use of chlorofluorocarbons in the early 1970s, their potential global consequences were ignored until the mid 1980s, when more definitive data made it apparent that ignoring the problem forever was not an option (Miller \& Mintzer, 1986; Shea, 1989). Or consider the whaling industry. Harvests by several countries did not abate until the large baleen species, one by one, reached commercial, though apparently not biological, extinction (Oldfield, 1989); that is, until it was no longer profitable to hunt. Over-exploitation of some resources leading to widespread ecological problems continues (e.g., Silver \& DeFries, 1990; Hecht \& Cockburn, 1990; Miller \& Tangley, 1991).

These cases all involve resources in which the size of the pool is difficult to measure and/or the costs of profligate use are externalized. Thus, the short-term benefits outweigh the short-term costs for users (people in DCs, or wealthier people in LDCs) and users have no individual incentive to conserve, but strong individual incentives to exploit.

Walters (1986) discussed the importance of feedback policies in managing renewable natural resources. Policies which mandate that harvest should decline if there are signs of stock depletion may well be essential for sustained harvest. Unfortunately, the quantities (pool size) of many resources are too poorly known, and the costs of use are so externalized, frequently across national boundaries, that adopting such policies at a local or even national level is sometimes not possible. International treatises and commissions are probably the only answer, if sufficient incentives can 
POPULATION AND ENVIRONMENT

be applied for individual nations to comply. Of course, other more localized conservation problems occur in the industrialized nations as well. However, the global issues discussed above are largely caused by industrialized nations and will be, we predict, the most difficult to solve because the benefits of industrialization may far outweigh the costs for citizens in those nations, and because the costs dissipate over the earth.

\section{Prediction [4] Sex Differences in Resource Use}

Because of the different shape of mating versus parental return curves (Low, 1990a), male and female humans, like other male and female mammals, should differ in the amount of resources they strive to acquire, and the risks they are willing to take:

[a] Societies in which women's resource-use patterns approximate men's should be those societies in which their return curves are similar (i.e., matrilineal societies in which a very large amount of resources, while not increasing a woman's fertility, may, because she can pass them to her son/s, increase her number of grandchildren).

[b] Because women's reproductive value, related to age, is important in mate selection, while for men, resource control is likely to be more important than age (Low, 1989a;b; 1990a;b), women's reproduction is unlikely to correlate with wealth, power, or status. Instead, even in cultural milieus (such as nineteenth century Sweden (Low, 1989b; 1990b)) in which marriage ages were late, women who marry earlier are likely to have higher lifetime fertility than women who marry later, while men's fertility tends to be related to their wealth and/or status, and not to their age of marriage.

[c] Because of the interplay of resource (male) and reproductive (female) values, in polygynous societies, men controlling more resources should marry more (and younger) women than do men with fewer resources. Even in monogamous societies, wealthier men may marry younger wives with higher reproductive value (sensu Fisher, 1958).

All of these predictions argue that in most societies, men can benefit more directly from resource exploitation, and are likely to be the driving force in risky, high-stakes resource garnering.

Men and women, like other male and female mammals, seek access to and control of resources toward somewhat different reproductive ends. Men's striving centers around the mating aspects of reproductive effort and operates in the community sphere (Whyte, 1978; 1979; Low, 1990a). Male resource competition and male-male coalitions are associated with status or resource competition (Chagnon, 1979; 1982; 1988), and with resources that can be more effectively obtained and protected by groups of 
BOBBI S. LOW AND JOEL T. HEINEN

males-war, heritable land of lasting value, some large game. While such coalitions are likely to be among brothers, and associated with patrilocal residence, more-or-less fluid coalitions of this sort arise among men of various relatedness, and among nonrelatives in many societies. Men's coalitions typically are broad-reaching, involve both more risk and higher reproductive stakes than women's coalitions, exerting considerable power, and controlling significant resources (e.g., Low, 1990a). Coalitions in other male and female mammals also follow these patterns.

Men in most societies for which there is information use resources to gain reproductively, typically through polygyny, i.e., additional wives. In polygynous human societies (the majority of traditional societies), like other mammalian species, variance in male reproduction is relatively high; great expenditure and great risk-taking may be profitable (Low, 1989a; $b$; 1990a;b). In more than a hundred well-studied societies (Betzig, 1986), there are clear formal reproductive rewards for men associated with status: High-ranking men have the right to more wives and have significantly more children than others. In most societies the relationship is quite straightforward: In the Turkmen, Irons (1979 a;b) found that richer men had more wives and more children than poorer men. Borgerhoff Mulder $(1988 ; 1990)$ found that in the African Kipsigis, richer men married younger wives (of higher reproductive value; Fisher, 1958) and produced more children than poorer men, although with the introduction of western technology and medicine, differentials were reduced. Even in societies such as the Yanomamö, in which few physical resources are owned, male kin for coalitions represent a resource, and men manipulate kinship terms in ways that make more women available for mates, and more powerful men available as partners (Chagnon, 1982); men who establish their bravery in revenge raids also have more wives and more children (Chagnon, 1988) so that reproductive success is uneven. In the Ache, too, good hunters have more children than other men (Hill \& Kaplan, 1988 a;b; Hawkes, 1989). On the island of Ifaluk, men who hold political power have more wives and more children than others (Turke \& Betzig, 1985). Even in ostensibly monogamous societies, monogamy may be far from absolute. In the Kalahari Bushmen, living in a resource-limited environment, $5 \%$ of the men manage to have two wives (Lee, 1979). In 10 of 12 societies reviewed in less detail by Hill (1984), resource control enhanced reproductive success. There is an intriguing parallel in nonhuman species: In ostensibly monogamous songbirds, males will sometimes take another mate-if resources are abundant (Gowaty et al., 1989).

For women, sufficient resources to raise healthy children are important, but there is little evidence that control of large amounts of resources has enhanced women's reproductive success throughout evolutionary his- 
tory, or cross-culturally today (Irons, 1979a;b; Borgerhoff Mulder, 1988; 1990). This is true despite the fact that in many societies, women actually provide the majority of the calories to the family's diet. Female-female coalitions may arise among female relatives or co-wives, and appear to function for the exchange of information (e.g., location of good foraging spots), child care, and subsistence-related work (cf. Irons, 1983; Low, 1990a). Resources garnered are used for offspring, family, and important reciprocators, and significant resource control is rare or unknown. These coalitions are almost never significant beyond the household boundaries; even female solidarity groups tend to be among relatives. Resources strongly affect women's reproduction when they are limiting (e.g., malnutrition), but can only be used by women to gain the extraordinary reproductive success of highly polygynous males (Betzig, 1986) in societies in which the descent system allows highly successful women to concentrate resources in their sons (Low, 1992).

In western technological monogamous societies today, including the United States, men typically remarry more often than women, and have children in second marriages more often than women; when this occurs, the society is rendered effectively polygynous (Daly \& Wilson, 1983; Hartung, 1982; Essock-Vitale, 1984). Further, U.S. census data suggest that family size increases with a man's income, even when second marriages are not considered (Daly \& Wilson, 1983, p. 334). When we look within societal groups in contemporary society, rather than across nations (e.g., Birdsall, 1980), richer men and families (but not women richer through their own employment), even today, have larger families (e.g., Voland, 1990; Hughes, 1986; Flinn, 1986; Daly \& Wilson, 1983, p. 334; Mueller, 1991; Rank, 1989; see review in Low \& Clarke, 1992). Some (e.g., Vining, 1986) have argued that these trends (richer men reproducing more than poorer men) are spurious, and that they seem to disappear when population growth stops. However, these analyses (e.g., Vining, 1986, Tables 2-5) use proxy measures like education rather than resources, and do not consider lifetime fertility; they are, at the very least, difficult to interpret. Thus even in industrialized societies, the possibility exists that richer men may derive immediate familial (reproductive) benefits from their resource acquisition. In sum, there are strong evolutionary reasons why, throughout our history, men have profited more from large-scale resource exploitation than women.

\section{Prediction [5] Conservation Strategies Likely to Succeed}

If enhancement of individual and familial survival and reproduction is the evolutionary context of resource striving, then our strategies for con- 
BOBBI S. LOW AND JOEL T. HEINEN

vincing people to shift resource use to more conserving patterns must appeal to their perceived short-term, familial and local, interests. No other species has evolved to behave in the long-term interests of the larger group (unless that group comprises only close relatives), at the expense of short-term individual and familial interests, and we propose that this is also true of humans.

If humans have evolved to use resources in reproductively selfish ways, then the most sucessful conservation strategies will be those whose benefits to individuals can be made to outweigh costs, through a system of economic or social incentives which confer immediate or very short-term benefits to individuals and/or their families and friends. If this is the case, governments and organizations may find it productive to implement policies that create systems of incentives to conserve; the more immediate and local the benefit, the more successful should be the outcome.

The actual monetary value of the proximate rewards need not be great. Consider, for example, "bucket" drives to collect money for various causes on the campus of a major university. Our argument suggests people will be more likely to give to a bucket drive if they get some immediate reward such as a pin or tag indicating that they gave. There are two rewards-the pin advertises the giver's generosity (which may elicit reciprocity) to everyone and also warns other bucket collectors not to bother the giver again. To test this hypothesis, we interviewed students on the main campus of the University of Michigan, asking them to which drives they gave, and whether they received some sort of tag or pin for their gift. Students were much more likely to give to drives in which a pin or tag is provided $\left(n=84, X^{2}=8.4, p<0.01\right)$. Yet the cost of each tag is a fraction of a cent, and most donors give a dollar or more. The American Red Cross uses a similar strategy during blood drives; pins are given which advertise "be nice to me: I gave blood today." Blood donors can aspire to become a "one gallon donor" or a "five gallon donor" with more badges (i.e., pins are given for each additional gallon, advertising the number of gallons donated). Other factors may operate in this case. Barbara Pate (personal communication), Regional Representative for the American Red Cross in Washtenaw County, Michigan, reports that the main reason people state for giving blood is that a friend or relative was in an accident or had an operation, and thus needed blood; people appear to be reciprocating consciously.

We are asking what people actually do, given the costs (a few bucks or a pint of blood) and the benefits (nothing versus a tag to advertise one's goodness, or help to a friend or relative versus help to a stranger), in such generalized reciprocity situations; this may provide clues for eliciting more widespread forms of conservation activities. We argue that, while many 
proximate motivations can prompt behavior, the greater the immediate individual benefit, or the lower the immediate individual cost, the more likely the behavior will be. The Peace Corps actively offers and advertises all of these direct benefits to prospective recruits. Beyond direct monetary incentives, the organization offers travel opportunities, challenges, opportunities for personal growth, and preprofessional experiences not available to most people in our society, resulting in greater employability. This organization uses extremely effective techniques, predictable from a evolutionary/behavioral approach, by developing direct and indirect incentives that appeal for many reasons to talented people to serve basic needs of the poor in lesser-developed countries; the Peace Corps seems to us an excellent example of promoting group-level benefits through offsetting some personal costs with individual benefits.

Other examples are closer to home. Consider the recycling of bottles in states with and without "bottle bills." Many communities in states without such bills have voluntary recycling centers, but few people use them. The cost of stopping at a center on the way somewhere is trivial, yet it is a cost that apparently few of us are willing to incur. We predict that the rate of recycling of the same bottles in states with bottle bills is much greater, probably approaching $100 \%$, though the incentive is also seemingly rather trivial ( $\$ 0.05$ to $\$ 0.10$ US for cans and bottles in the state of Michigan). For example, the Ann Arbor Ecology Center (personal communication) reports that over $90 \%$ of redeemable beverage containers are returned by the buyer in states with bottle bills such as Michigan; this is reported to be the most effective type of recycling program. A small monetary reward (or fine if one does not collect) is sufficient to bring the point (and the bottles) home. Furthermore, in areas where people have to pay for garbage disposal on a volumetric basis, and recycling is provided free of charge, though not mandatory, up to $90 \%$ of households do at least some recycling. Compare this to the approximately $23 \%$ participation in cities like Ann Arbor, Michigan, in which there was free voluntary curbside recycling, but garbage fees were assessed per household, not on a volumetric basis (the laws in Ann Arbor have been changed recently, and recycling is now over $80 \%$ ). People are much more likely to recycle bottles and cans redeemable for even a trivial reward (Figure 2). The lessons from these minor examples should be obvious for states or municipalities wishing to reduce solid wastes as landfills reach capacity (e.g., Young, 1991): people are more likely to take part in programs whose benefits are societal if they have direct individual incentives (Rathje \& Murphy, 1992). These benefits do not have to reach economic parity; often, rewards that would be ridiculously small in any economic analysis can be effective. 
BOBBI S. LOW AND JOEL T. HEINEN

FIGURE 2. For most materials, whether recycling occurred depended on whether a refund was offered. Organic materials were defined as recycled when composted. Data from 240 University of Michigan undergraduates, 1989.

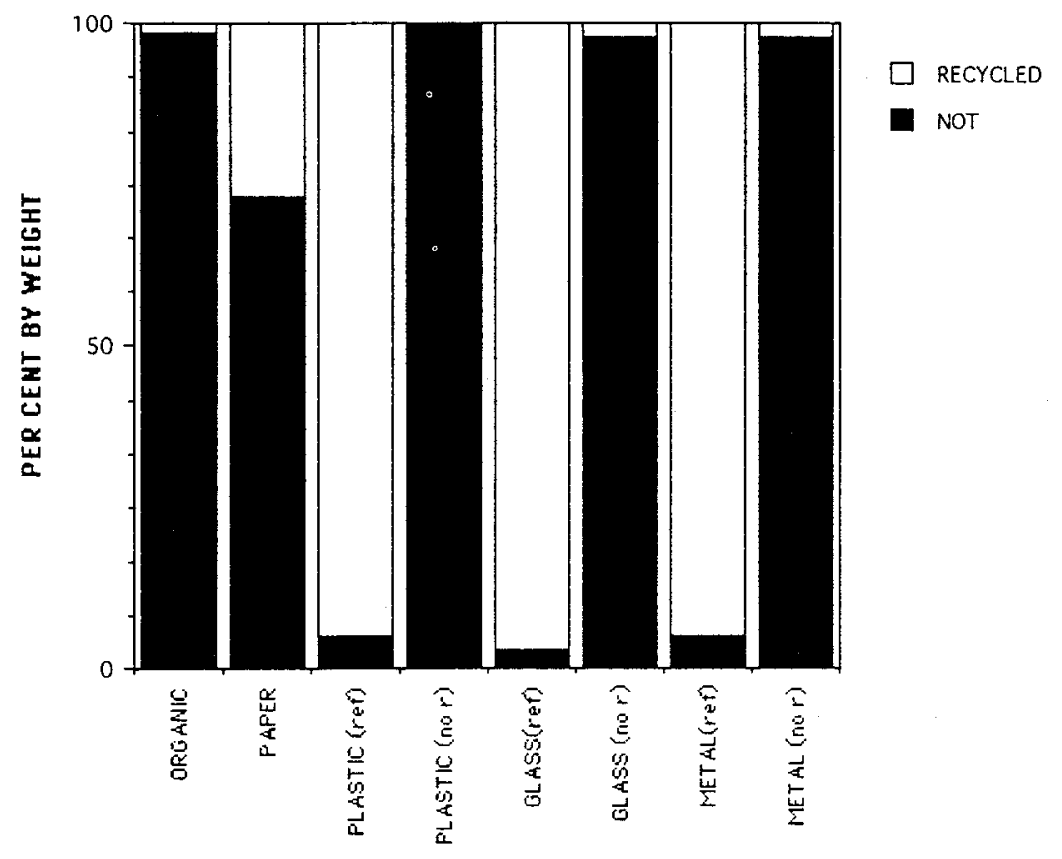

Can we apply the same principles to wider-ranging resource issues? The most difficult resource-use problems have the following characteristics: resource base inadequately known and feedback slow, used by many, unrelated individuals, and externalized costs. Even in these cases, if incentives can be provided to individuals we expect use patterns to change. Monetary incentives, as we noted, need not be great. If the problem is sufficiently immediate-affecting individuals, and in the short-termother, nonmonetary incentives can be effective, especially if they play on our evolved psychological mechanisms. Most frequently studied proximate motivators are: education, and intrinsic and social motivation (e.g., DeYoung, 1985; Kaplan \& Kaplan, 1982; DeYoung \& Kaplan, 1988; Monroe \& Kaplan, 1988; and Stapp et al., 1988). Educational techniques seek to change behavior by increasing understanding/information about the impact 
of behavior. Several components are felt to be necessary: awareness, knowledge, attitude modification, skills and participation (Monroe \& Kaplan, 1988; Stapp et al., 1988). Feedback (including information about impact and implicit goals) has been very effective in promoting energy conservation (Seligman et al., 1981). However, the overall effectiveness of information on encouraging conservation is unresolved. DeYoung (1989) found information on recycling procedures to be very effective; while Hopper et al. (1991) found that although information increased recycling behavior, it was less effective than other strategies.

The most intractable resource abuse examples involve slow feedback cycles and sparse or unreliable information; we also would argue that problems like local recycling efforts (which have some relatively immediate and personal costs and benefits) would be more easily tackled with educational efforts and appeals to help the community by "doing the right thing" than, for example, drought in Ethiopia or the price of gasoline. The cost of gasoline is currently much greater (three to six times) in Europe versus the United States of America; use per capita in Europe is much lower, as a consequence of price, distances between living and working places and availability of alternative transportation. In the United States, we are certainly aware of the problem, but it is obviously politically difficult to pass new taxes in the United States (for precisely the reasons we have outlined). The recent analysis of energy policy by Cowhey (1985) is a sterling example of crisis policy management in the face of conflicts of interest at a number of levels: government, individual politician, company CEOs. For the reasons Cowhey gives it would be difficult to raises gas taxes even though it is clear that if this were done, incentives for alternative energy sources and alternative (mass) transit would be created. The difficulty in this case would be to convince voters and members of Congress from the industrialized states to pass such a tax, due to the immediate costs of taxation to consumers and to the auto industry; the immediate individual costs to a politician promoting tax increases are seldom seen as counterbalanced by the longterm societal gain. Such an attempt would internalize the costs of fossil fuels and reduce consumption by forcing consumers to pay immediate costs.

This part of the process is difficult to achieve, and more difficult the larger and more diverse the society, because it requires coalitions of individuals willing to impose costs on themselves as well as on others in the short term. As Daly and Cobb (1989) pointed out, the rational behavior of an individual, given the current incentive system, is not necessarily a rational policy for society as a whole. With these complex problems, the question then becomes how to change incentives so that individuals will will- 
BOBBI S. LOW AND JOEL T. HEINEN

ingly behave in ways that benefit society, or how to foster coalitions (e.g., to pass "green fees") which will force us to act in our longer-term interests.

\section{CONCLUSIONS: WHAT CAN WE DO?}

If conventional wisdoms were true, resource abuse would increase with degree of technology, and information about the effects of our actions would be sufficient to solve ecological problems, as individuals accepted costs for the common good. Information appropriate for analyzing these complex problems is scattered, and often it is difficult or impossible to accomplish the level of analysis we would wish. Yet it is clear that neither of the predictions from conventional wisdom are supported: Resource abuse sometimes accompanies technological innovation, but only if individuals can benefit in the short term. When shifts in cultural values occur, they are secondary. Of conservation efforts in the last twenty years, those based solely on information are arguably less successful than those incorporating an individual cost-benefit leverage. Note, though, that, particularly at local levels, advertising social costs and benefits-e.g., "doing the right thing"-can be effective. Thus, education seems most effective when employed on relatively local problems, problems with individual costs and benefits (e.g., recycling and landfills).

The principal alternative to our conventional wisdom, the behavioral ecological paradigm, suggests that our complex human intelligence, like our cooperative behavior, evolved in competition with other human groups, and has always been directed toward our own familial short-term benefit-even when we can see clearly that longterm societal, or even global, detriment may result.

The behavioral ecological paradigm predicts that one effective way to change patterns of resource use is to examine people's perceived shortterm benefits and play on those, creating individual (and corporate) shortterm benefits (for compliance), or costs (for defection) in cases in which the behavior will have long-term societal benefit. At one level, the logic we propose, that individuals calculate (though not necessarily consciously) their benefits and costs in any action, has been said or implied by others (e.g., McNeely, 1988; and many entries in Hardin \& Baden, 1977).

We argue that the cost and benefit currencies were not originally, and need not be, monetary. Our costs and benefits as a social primate are older than the invention of barter and money, although not older than family structure and reciprocity. If we are right, some solutions may come more easily than if we had to rely solely on economic levers; potentially impor- 
tant rewards include advertising one's status as a good cooperator. We evolved as a highly social species, and reciprocity is a powerful force, one we have probably underestimated in our attempts to encourage such behaviors as recycling. Even our brief review above suggests this. It may even be possible to manipulate an extension of our definitions of "family" or shared interest in real ways, to the benefit of conservation programs. These techniques have been extraordinarily successful in the service of other ends (e.g., training for warfare; Holmes, 1985). Throughout our evolutionary history, most conflicts were fought by individuals or small groups of related men, and most conflicts were fought over reproductively important matters (Manson \& Wrangham, 1991; Low, in press). It is not coincidental that successful training eliminates many differences in appearance with haircuts and uniforms; that it uses kinship and reciprocity terms; that units are trained and moved together so that one's life depends on men one knows (with notable failures like Vietnam, where individuals were rotated: Hackworth, 1989). In short, training mimics the kin warfare situation of our evolutionary past. If we can call more widely on analogous strategies in the service of conservation (e.g., Peace Corps, Conservation Corps), perhaps we can add a powerful strategy producing group-level benefits.

How can we foster strong normative conservation ethics, if we wish to? Williams (1989) called evolution "immoral," because it fosters the traits we described. While we would call natural selection amoral, because the traits it favors in all living organisms evolved long before, and outside the context of, our cultural perceptions of them, Williams makes an important point: If we try to overlook the fact that selection uniformly favors genotypically selfish behavior, we have no hope of countering these pressures. The only strategies likely to work consistently are those that manipulate individual, familial, and reciprocal costs and benefits. It is time to examine what such costs and benefits might be.

Defining manageable portions of the problems to be tackled ("think globally, act locally") seems to be an important strategic device, related to our evolutionary past in small groups with shared interests. As we have argued, shared interests are key. It is simply too overwhelming to think concurrently of whole litanies of problems, like the lists we made in our introduction; our response is to sink into passive despair. As Weick (1984) noted, such litanies disable the very resources of thought and action necessary to change them. Instead, he argues, building a series of "small wins" creates a sense of control, reduces frustration and anxiety, and fosters continued enthusiasm. Ostrom (1990, p. 90) summarizes the traits of successful cooperative groups.

Information about the effects of our behavior is obviously important; 
BOBBI S. LOW AND JOEL T. HEINEN

ultimately, self-interest dictates avoiding our own destruction. However, probably because of the great changes in the scope of time and space involved, our recent history suggests that information alone will not be sufficient to change people's behavior. If the change is seen as costly in individual time, money, or even attention, more than simple information may be required to effect change. Many solutions to resource problems may lie in adopting conservation strategies that provide direct individual or familial benefits, or advertisements to potential reciprocators, as well as monetary advantages.

Because of our inescapable history as a long-lived, social primate, we also possess evolved proximate mechanisms to maximize our functioning in the social context. If we can play upon these evolved mechanisms, again, we may be able to promote conservation strategies more effectively than if we require conscious cost-benefit calculations, or rely solely upon economic costs and benefits.

Because cultural transmission is so very important (though not unique) in humans (e.g., Lumsden \& Wilson, 1981; Cavalli-Sforza \& Feldman, 1981; Boyd \& Richerson, 1985, Hamilton, 1975), we have evolved to be "docile"-disposed to be taught (Simon 1990). Though there are sex differences in the intensity of training to be obedient, even boys in highly polygynous societies in which ferocity and aggression abound are taught to obey their elders (Low, 1989a). Thus it will not surprise us that children raised in a conservation ethic might, as adults, find it less onerous than their parents did to perform slightly (phenotypically) costly behaviors which will have a longer-term benefit for the group. Similarly, the promotion of conservation ethics as a social norm (if one "ought" to do it, it can be socially costly to defect; e.g., Myers, 1990) may be helpful.

If we can "think globally, act locally," not only can problems be made more manageable, but the strong forces of social norms (including coersion through legal means) and reciprocity may be brought into play. That is, among non-relatives, our neighbors are those with whom we are most likely both to have had (socially) profitable reciprocal relationships, and those on whom we are least likely to defect (e.g., in tit-for-tat games, repeated interaction is important; Axelrod and Hamilton 1981, Axelrod, 1984, Axelrod and Dion, 1988). As we promote a normative standard regarding conservation, compliance is likelty to be higher the better we know, the more we interact with, and the more affected are our neighbors (the well-known "bystander effect" [Latane and Rodin, 1969] notes that when there are sufficient bystanders, people defect-their chance of remaining anonymous is greater). Information, reciprocal interactions, and promotion of social norms, are all likely to be more effective when trans- 
lated into local scenarios with immediate payoffs. The more remote or uncertain are future benefits, the more we "discount" - the difficulties of solving problems increase with anonymity, separation of costs and benefits across individuals, time, and space (see Heinen and Low, 1992; Hannon, 1987; Fuchs, 1983; Cropper et al., 1991). How much time do we have? If it takes a generation or two to create socially altruistic, group-benefit oriented individuals, what will remain for them to save? We need to work in both the short and long term, using both economic and social costs and benefits, and designing education and social norm strategies on the most local scale we can.

\section{ACKNOWLEDGEMENTS}

A number of colleagues read and criticized various drafts. We are particularly indebted to Bill Stapp, Beverly Strassman, Ken Lockridge, Bob Smuts, Garry Brewer, R. D. Alexander, Dave Zaber, Dave White, Ray De Young, Shannon Sullivan, Paul Turke, and the members of the Human Behavior and Evolution Program at the University of Michigan; to George Williams, SUNY Stony Brook, R. Paul Shaw, of the World Bank, Stanton Braude, Univ. Missouri St. Louis, Henry Harpending, of Pennsylvania State University, and Martin Daly and Margo Wilson of McMaster University.

\section{REFERENCES}

Alcock, J. (1984). Animal behavior: An evolutionary approach (third edition). Sunderland, Mass: Sinauer Associates.

Alexander, R. D. (1971). The search for an evolutionary philosophy of man. Proc. Roy. Soc. Victoria, Melbourne, 84,99-120.

Alexander, R. D. (1974). The evolution of social behavior. Ann. Rev. Ecology and Systematics, 5, 325-383.

Alexander, R. D. (1979). Darwinism and human affairs. Seattle: University of Washington Press.

Alexander, R. D. (1987). The biology of moral systems. New York: Aldine De Gruyter.

Anderson, A. (1984). The extinction of the moa in southern New Zealand. In Paul S. Martin \& Richard G. Klein (Eds.). Quarternary extinctions: A prehistoric revolution (pp. 728-740). Tucson: Arizona University Press.

Anonymous. (1985). Common crisis North-South: Co-operation for world recovery. The Brant Commission. Cambridge, Mass: MIT Press.

Axelrod, R. (1984). The evolution of cooperation. New York: Basic Books.

Axelrod, R., \& Dion, D. (1988). The further evolution of cooperation. Science, 242, 1385-90.

Axelrod, R., \& Hamilton, W. D. (1981). The evolution of cooperation. Science, 211, 1390-1396.

Betzig, L. L. (1986). Despotism and differential reproduction: A Darwinian view of history. New York: Aldine. 
BOBBI S. LOW AND JOEL T. HEINEN

Birdsall, N. (1980). Population growth and poverty in the developing world. Population Bulletin, 35(5), 3-47.

Bodley, 1. H. (1990). Victims of progress (third edition). Mountain View, CA: Mayfield Publishing.

Borgerhoff Mulder, M. (1988). Kipsigis bridewealth payments. In Laura Betzig, Monique Borgerhoff Mulder, \& Paul Turke (Eds.). Human reproductive behavior: A Darwinian perspective (pp. 65-82). Cambridge: Cambridge University Press.

ㄴ.. (1990). Kipsigis women's preferences for wealthy men: evidence for female choice in mammals? Behav. Ecol. Sociobiol, 27, 255-264.

Boswell, J. (1988). The kindness of strangers: The abandonment of children in western Europe from late antiquity to the renaissance. New York: Random House.

Boulding, K. E. (1977). Commons and community: The idea of a public. In Garrett Hardin \& John Baden (Eds.). Managing the Commons, (pp 280-294). San Francisco: Freeman.

Boyd, Robert, \& Richerson, Peter-1. (1985). Culture and the evolutionary process. Chicago: University of Chicago Press.

Brown, L. R. (1990). The illusion of progress. In L. R. Brown (Ed.). State of the world 1990: A Worldwatch Institute report on progress for a sustainable society, (pp 3-16), New York: W.W. Norton and Co.

Brown, L. R. (1991). The new world order. In L. R. Brown (Ed.). State of the world 1991: A Worldwatch institute report on progress for a sustainable society, (pp 3-20). New York: W.W. Norton and Co.

Bunker, S. G. (1985). Underdeveloping the Amazon. Chicago: University of Chicago Press.

Callicott, J. B. (1989). In defense of the land ethic. Albany: State University of New York Press.

Callicott, J. B. \& Ames, R.T. (1989). Nature in Asian traditions of thought. Albany: State University of New York Press.

Cassels, R. (1984). Faunal extinctions and prehistoric man in New Zealand and the Pacific Islands. In Paul S. Martin \& Richard G. Klein (Eds.). Quaternary extinctions: A prehistoric revolution, (pp 741-767). Tucson: Arizona University Press.

Cavalli-Sforza, L. L., \& Feldman, M. W. (1981). Cultural transmission and evolution. Princeton: Princeton University Press.

Chagnon, N. (1979). Is reproductive success equal in egalitarian societies? In N. A. Chagnon \& W. Irons (Eds.). Evolutionary biology and human social behavior: An anthropological perspective. North Scituate, MA: Duxbury Press.

Chagnon, N. (1982). Sociodemographic attributes of nepotism in tribal populations: Man the rule-breaker. In Kings' College Sociobiology Group (Eds.). Current problems in sociobiology. Cambridge: Cambridge University Press.

Chagnon, N. (1988). Life histories, blood revenge, and warfare in a tribal population. Science, 239, 985-992.

Chapman, M. D. (1989). The political ecology of fisheries depletion in Amazonia. Environmental Conservation, 16(4), 231-237.

Chiras, D. D. (1988). Environmental science: A framework for decision making (second edition). Menlo Park, CA: Benjamin Cummings.

Clay, J. W. (1988). Indigenous peoples and tropical forests. Cambridge, MA: Cultural Survival, Inc.

Cowhey, Peter F. (1985). The problems of plenty: Energy policy and international politics. Berkeley: University of California Press.

Cropper, M. L., Aydede, S. K. \& Portney, P. R. 1991. Discounting human lives. Amer. J. Agric. Econ., Dec. 1991: 1410-1415.

Crosby, A. W. (1986). Ecological imperialism: The biological expansion of Europe, 900-1900. Cambridge: Cambridge University Press.

Crowfoot, J. E. \& Wondolleck, J. M. (1990). Environmental disputes: Community involvement in conflict resolution. Washington, D.C: Island Press. 
POPULATION AND ENVIRONMENT

Daly, H. E. \& Cobb Jr, J. B. (1989). For the common good: Redirecting the economy toward community, the environment, and a sustainable future. Boston: Beacon Press.

Daly, M., \& Wilson, M. (1983). Sex, evolution, and behavior, 2nd ed. Boston: Willard Grant Press.

Darwin, C. (1859). On the origin of species by means of natural selection. Facsimile of the first edition, with an introduction by Ernst Mayr, published 1987. Cambridge, MA: Harvard Univ. Press.

Darwin, C. (1871). The Descent of man and selection in relation to sex. New York: Appleton.

Dawkins, R. (1976). The selfish gene, New Edition. Oxford: Oxford University Press.

Dawkins, R. (1982). The extended phenotype: The gene as the unit of selection. Oxford: Oxford University Press.

Dawkins, R. 1986. The blind watchmaker. New York: W.W. Norton and Co.

Deevey, E. S., Rice, D. S., Rice, P. M., Vaughan, H. H., Brenner, M., Flannery, M. S., (1979). Mayan urbanism: Impact on a tropical karst environment. Science, 206, 298-305.

DeYoung, Raymond. (1985). Encouraging environmentally appropriate behavior: The role of intrinsic motivation. I. Environmental Systems, 15, 281-292.

DeYoung, Raymond. (1989). Exploring the difference between recyclers and non-recyclers: The role of information. I. Environmental Systems, 18, 341-351.

DeYoung, Raymond \& Kaplan, Stephen (1988). On averting the tragedy of the commons. Environmental Management, 12, 273-283.

Devall, W. \& Sessions, G. (1985). Deep ecology. Salt Lake City: Peregrine Smith Books

Dewsbury, D. A. (1978). Comparative animal behavior. New York: McGraw-Hill.

Diamond, J. M. (1984). Historic extinction: A rosetta stone for understanding prehistoric extinctions. In Paul S. Martin \& Richard G. Klein (Eds.). Quaternary extinctions: A prehistoric revolution, (pp. 824-866). Tucson: Arizona University Press.

Dixon, I. A. \& Sherman, P.B. (1990). Economics of protected areas: A new look at benefits and costs. Washington, D.C: Island Press.

Dove, M. R. (1988). Introduction: Traditional culture and development in contemporary Indonesia. In M. R. Dove (Ed.). The real and imagined role of culture in development: Case studies from Indonesia, (pp. 1-37). Honolulu: University of Hawaii Press.

Drake, M. (1969). Population and society in Norway: 1735-1865. Cambridge: Cambridge University Press.

Drury, W. H. (1973). Population changes in New England seabirds. Bird Banding, 44, 267. 313.

Durning, A. (1991). Asking how much is enough. In Brown, L.R. (Ed.). State of the world 1991: A Worldwatch Institute report on progress for a sustainable society, (pp. 153-169). New York: W.W. Norton and Co.

Edgerton, L. T. (1991). The rising tide: Clobal warming and world sea levels. Washington, D.C: Island Press.

Ehrlich, P. R. \& A. H. Ehrlich. (1981). Extinction: The causes and consequences of the disappearance of species. New York: Random House.

Ehrlich, P. R., \& Ehrlich, A. H. (1990). The population bomb. New York: Simon and Schuster.

Essock-Vitale, S. M. (1984). The reproductive success of wealth Americans. Ethology and Sociobiology, 5, 45-49.

Fisher, R. A. (1958). The genetical theory of natural selection. New York: Dover Books.

Flinn, M. V. (1986). Correlates of reproductive success in a Caribbean village. Human Ecology, 14, 225-243.

Fuchs, V. R. (1982). Economic aspects of health. Chicago: University of Chicago Press.

Goodall, J. (1986). The chimpanzees of Combe: Patterns of behavior. Cambridge: Belknap Press of Harvard University Press.

Gowaty, P. A., Plissner, J. H., \& Williams, T. G. (1989). Behavioral correlates of uncertain parentage: Mate guarding and nest guarding by Eastern Bluebirds, Sialia sialis. Anim. Behav. 38(2), 272-284. 
BOBBI S. LOW AND JOEL T. HEINEN

Hackworth, D. H. (1989). About face: The odyssey of an American warrior. With Julie Sherman. New York: Simon and Schuster.

Haines, F. (1970). The buffalo: The story of American bison and their hunters from prehistoric times to the present. New York: Thomas Y. Crowell Co.

Hames, R. (1979). A comparison of the shotgun and the bow in neotropical forest hunting. Human Ecology, 7, 219-252.

Hames, R. (1989). Time, efficiency, and fitness in the Amazonian protein quest. Res. Econom. Anthropol. 11: 43-85.

Hames, R. (1991). Wildlife conservation in tribal societies. In M. L. Oldfield \& \}. B. Alcorn (Eds.). Biodiversity: Culture, conservation and ecodevelopment (pp. 172-199). Boulder: Westview Press.

Hamilton, W. D. (1964). The genetical evolution of social behavior I,II. I. Theoretical Biology, 7, 1-52.

Hamilton, W. D. (1975). Innate social aptitudes of man: An approach from evolutionary genetics. In Robin Fox (Ed.). Biosocial anthropology, pp. 133-155. London: Malaby Press.

Hannon, B. (1987). The discounting of concern. In Pillet, G. \& Murota, T. (Eds.). Environmental economics (pp. 227-241).

Hardin, G. (1968). The tragedy of the commons. Science, 162, 1243-1248.

Hardin, G. \& Baden, J. (Eds.). Managing the commons. San Francisco: W. H. Freeman.

Hargrove, E. C. (1988). Foundations of environmental ethics. Englewood Cliffs, NJ: Prentice Hall.

Harrison, P. (1987). The greening of Africa, London: Paladin Press.

Hartung, J. (1982). Polygyny and the inheritance of wealth. Current Anthropol., 23, 1-12.

Hausfater, G. \& Hrdy, S. B. (Eds.). (1984). Infanticide: Comparative and evolutionary perspectives. New York: Aldine.

Hawkes, K. 1989. Why do men hunt? Benefits for risky choices. In E. Cashdam (Ed.). Risk and uncertainty in tribal and peasant economies. (pp. 145-166). Boulder: Westview.

Hawkes, K. \& Charnov, E. L. (1988). On human fertility: Individual or group benefit? Current Anthropol., 29, 469-471.

Hecht, S. \& Cockburn, A. (1990). The fate of the forest: Developers, destroyers, and defendors of the Amazon. New York: Harper Collins.

Heinen, J. T. \& Kattel, B. (1992). Parks, people, and conservation: A review of management issues in Nepal's protected areas. Population and Environment 14 (1): 49-84.

Hill, 1. (1984). Prestige and reproductive success in man. Ethology and Sociobiol, 5, 77. 95.

Hill, K. \& H. Kaplan. 1988a. Tradeoffs in male and female reproductive strategies among the Ache: Part 1. In L. Betzig, M. Borgerhoff Mulder, \& P. Turke (Eds.). Human reproductive behavior: A Darwinian perspective. Cambridge: Cambridge University Press.

Hill, K. \& Kaplan, H. (1988b). Tradeoffs in male and female reproductive strategies among the Ache: Part 2. In L. Betzig, M. Borgerhoff Mulder, \& P. Turke (Eds.). Human reproductive behavior: A Darwinian perspective. Cambridge: Cambridge University Press.

Holmes, R. (1985). Acts of war: The behavior of men in battle. New York: Free Press.

Hopper, Joseph R., Nielsen, Joyce McCarl (1991). Recycling as an altruistic behavior: Normative and behavioral strategies to expand participation in a community recycling program. Environment and Behavior, 2, 195-220.

Hough, J. L. \& Sherpa, M. N. (1989). Bottom up vs. basic needs: Integrated conservation and development in the Annapurna and Michuru Mountain Conservation Areas of Nepal and Malawi. Ambio, 18(8), 434-441.

Hughes, A. L. (1986). Reproductive success and occupational class in eighteenth-century Lancashire, England. Social Biology, 33, 109-115.

Humphrey, N. K. (1983). Consciousness regained: Chapters in the development of mind. Oxford: Oxford University Press.

Irons, W. (1979a). Natural selection, adaptation, and human social behavior. In N. A. Chag- 


\section{POPULATION AND ENVIRONMENT}

non \& W. Irons (Eds.). Evolutionary biology and human social behavior: An anthropological perspective. North Scituate, MA: Duxbury Press.

Irons, W. (1979b). Emic and reproductive success. In N. A. Chagnon \& W. Irons (Eds.). Evolutionary biology and human social behavior: An anthropological perspective. North Scituate, MA: Duxbury Press.

Irons, W. (1983). Human female reproductive strategies. In S. Wasser (Ed.). Social behavior of female vertebrates. New York: Academic Press.

Kadlec, J. A. \& Drury, W. A. (1968). Structure of the New England herring gull population. Ecology, 49, 644-676.

Kaplan, S., \& Kaplan, R. (1982). Humanscape: Environments for people. Ulrich's Books, Ann Arbor.

Knodel, J. (1988). Demographic behavior in the past: German village populations in the 18th and 19 th centuries. Cambridge: Cambridge University Press.

Krebs, J. R. \& Davies, N. B. (1981). An introduction to behavioral ecology. Sunderland, MA Sinauer Associates.

Krebs, J. R. \& Davies, N. B. (1991). Behavioral ecology: An evolutionary approach. 3rd ed. Sunderland, MA: Sinauer Associates.

Latane, B. \& Rodin, J. (1969). A lady in distress:Inhibiting effects of friends and strangers on bystander intervention. /. Experimental Social Psychology, 5, 189-202.

Lee, R. B. (1979). The !Kung San. London: Cambridge Univ. Press.

Lockridge, K. A. (1983). The fertility transition in Sweden: A preliminary look at smaller geographic units, 1855-1890. Demographic Database, Umeå University Report No. 3. $140 \mathrm{pp}$.

Lovelock, J. E. (1979). GAIA: A New Look at Life on Earth. Oxford: Oxford University Press.

Low, B. S. (1989a). Cross-cultural patterns in the training of children: An evolutionary perspective. I. Comparative Psychology, 103, 311-319.

Low, B. S. (1989b). Occupational status and reproductive behavior in 19th century Sweden: Locknevi parish. Social Biology, 36, 82-101.

Low, B. S. (1990a). Sex, power, and resources: Ecological and social correlates of sex differences. I. Contemporary Sociology, 27, 45-71.

Low, B. S. (1990b). Land ownership, occupational status, and reproductive behavior in 19th century Sweden: Tuna parish. Amer. Anthropologist, 92(2), 457-468. illustr.

Low, B. S. (1992). Sex, coalitions, and politics in pre-industrial societies. Politics and the Life Sciences 11: 63-80

Low, B. S. (In press). An evolutionary perspective on warfare. In $\mathrm{H}$. Jacobson \& W. Zimmerman (Eds.). New thinking in a new world of security. Ann Arbor: Univ. Michigan Press.

Low, B. S. \& Clarke, A. L. (1992). Resources and the life course: Patterns in the demographic transition. Ethology and Sociobiology 13: 463-494.

Lowdermilk, W. C. (1953). Conquest of the land through 7000 years. Washington: U.S.Dept. of Agriculture.

Lumsden, C. J. \& Wilson, E. O. (1981). Genes, mind, and culture: The coevolutionary process. Cambridge MA: Harvard University Press.

Manson, Joseph \& Wrangham, R. W. (1991). Intergroup aggression in chimpanzees and humans. Current Anthropology, 32, 369-390.

Martin, P. S. (1984). Prehistoric overkill: The global model. In Paul S. Martin \& Richard G. Klein (Eds.). Quarternary extinctions: A prehistoric revolution (pp. 354-401). Tucson: Arizona University Press.

Mclntosh, R. P. (1985). The background of ecology: Concept and theory. Cambridge: Cambridge University Press.

McNeely, J. A. (1988). Economics and biological diversity: Developing and using economic incentives to conserve biological resources. Gland, Switzerland: IUCN Publication Services. 
BOBBI S. LOW AND JOEL T. HEINEN

Miller, A. S. \& Mintzer, I. M. (1986). The sky is the limit: Strategies for protecting the ozone layer. Washington, D.C: World Resources Institute. Research Report \#3.

Miller, K. R. \& Tangley, L. (1991). Trees of life: Saving tropical forests and their biological wealth. Boston: Beacon Ress.

Minnis, P. E. (1985). Social adaptation to food stress: A prehistoric southwestern example. Chicago: University of Chicago Press Prehistoric Archaeology and Ecology Series.

Mintzer, I. M. (1987). A matter of degrees: The potential for controlling the greenhouse effect. Washington, D.C: World Resources Institute. Research Report \#5.

Moench, M. (1989). Forest degradation and the structure of biomass utilization in a Himalayan Foothills village. Environmental Conservation, 16(2), 137-146.

Monroe, Martha \& Kaplan, S. (1988). When words speak louder than actions: Environmental problem solving in the classroom. I. Environmental Education, 19, 38-41.

Mueller, U. (1991). Social and reproductive success. Theoretical considerations and a case study of the West Point Class of 1950. ZUMA: Zentrum für Umfragen, Methoden und Analysen.

Murdock, W. W. (1980). The poverty of nations: The political economy of hunger and population. Baltimore: The Johns Hopkins University Press.

Myers, D. G. (1990). Social psychology. New York: McGraw Hill.

Myers, N. (1984). The primary source. London: W.W. Norton and Co.

Newman, P. C. (1989). Empire of the Bay: An illustrated history of the Hudson's Bay Company. New York: Viking.

Ogden, J. M. \& Williams, R. H. (1989). Solar hydrogen: Moving beyond fossil fuels. Washington, D.C: World Resources Institute.

Oldfield, M. L. (1989). The value of conserving genetic resources. Sunderland, Mass: Sinauer Associate.

Olson, S. L. \& James, H. F. (1984). The role of Polynesians in the extinction of avifauna of the Hawaiian Islands. In Paul S. Martin \& Richard G. Klein (Eds.). Quaternary extinctions: A prehistoric revolution (pp. 768-780). Tucson: Arizona University Press.

Ostrom, E. (1990). Governing the commons: The evolution of institutions for collective action. Cambridge: Cambridge University Press.

Pearson, C. S. (1985). Down to Business: Multinational Corporations, the Environment, and Development. Washington, D.C: World Resources Institute Study 2.

Peluso, N. L., Poffenberger, M. \& Seymour, F. Reorienting forest management on Java. In M. Poffenberger (Ed.). Keepers of the Forest: Land Management Alternatives in Southeast Asia, (pp 220-236). West Hartord, CT: Kumarian Press.

Podolsky, R. H. (1985). Colony formation and attraction of the Laysan albatross and the Leach's storm-petral. Unpubl. PhD Thesis. The University of Michigan, Ann Arbor.

Pragtong, K. \& Thomas, D. E. (1990). Evolving management systems in Thailand. In M. Poffenberger (Ed.). Keepers of the Forest: Land Management Alternatives in Southeast Asia, pp. 167-186. West Hartford, CT: Kumarian Press.

Prescott-Allen, C. \& Prescott-Allen, R. (1987). The first resource: Wild species in the North American economy. New Haven: Yale University Press.

Rank, M. A. (1989). Fertility among women on welfare: Incidence and determinants. Amer. Sociological Review, 54, 296-304.

Rathje, W. \& Murphy, C. (1992). Rubbish! The archaeology of garbage. New York: Harper Collins.

Renner, M. (1989). Rethinking Transportation. In Brown, L.R. (Ed.). State of the world 1989: A Worldwatch Institute report on progress for a sustainable society (pp 97-112). New York: W.W. Norton and Co.

Repetto, R. (1986). World enough and time: Successful strategies for resource management. New Haven: Yale University Press.

Revelle, P. \& Revelle, C. (1988). The Environment: Issues and choices for society (third edition). Boston: Portola Publishers. 


\section{POPULATION AND ENVIRONMENT}

Salisbury, R. F. (1962). From stone to steel: Economic consequences of a technological change in New Guinea. Cambridge: Cambridge University Press.

Seeley, T. D. (1985). Honeybee ecology: A study of adaptation in social life. Princeton: Princeton University Press.

Seligman, C., Becker, L. \& Darley, J. M. (1981). Encouraging residential energy conservation through feedback. In A. BAum \& J. L. Singer (Eds.). Advances in environmental psychology, Volume 3: Energy: Psychological perspectives. Hillsdale, NJ: Erlbaum.

Shaw, R. P. (1989). Rapid population growth and environmental degradation: Ultimate versus proximate factors. Environmental Conservation, 16(3), 199-208.

Shea, C. P. (1989). Protecting the Ozone layer In L. R. Brown (Ed.). State of the world 1989 A Worldwatch Institute report on progress for a sustainable society (pp 77-96). New York: W.W. Norton and Co.

Silver, C. S. \& DeFries, R. S. (1990). One earth one future: Our changing global environment. Washington, D.C: National Academy Press.

Simon, Herbert A. (1990). A mechanism for social selection and successful altruism. Science, 250, 1665-1668.

Smith, D. M. (1982). Where the grass is greener: Living in an unequal world. Harmondsworth, England: Penguin.

Speth, J. D. (1983). Bison kills and bone counts: Decision making by ancient hunters. Chicago: University of Chicago Prehistoric Archaeology and Ecology Series.

Spoehr, A. (1956). Cultural differences in the interpretation of natural resources. In William L. Thomas, Jr. (Ed.). Man's role in changing the face of the earth. An International Symposium under the Co-Chairmanship of Carl O. Sauer, Marston Bates, and Lewis Mumford (pp 93-102). Chicago: University of Chicago Press.

Stapp, W., Bull, I. Cromwell, M., Cwickel, J. W., DiChiro, G., Guarino, I., Rethje, R., Wals, A. \& Youngquist, M. (1988). Education in action: A community problem solving program for schools. Dexter, Ml: Thomson-Shore, Inc.

Strong, D. H. (1988). Dreamers and defenders: American conservationists. Lincoln: University of Nebraska Press.

Taylor, P. W. (1986). Respect for nature: A theory of environmental ethics. Princeton: Princeton University Press.

Trivers, R. L. (1971). The evolution of reciprocal altruism. Quart. Rev. Biology, 46, 35-57.

Trivers, R. L. (1985). Social evolution. Menlo Park, CA: Benjamin Cummings.

Trotter, M. M. \& MCCullough, B. (1984). Moas, men, and middens. In Paul S. Martin \& Richard G. Klein (Eds.). Quaternary extinctions: A prehistoric revolution (pp. 708-727). Tucson: Arizona University Press.

Turnbull, C. M. (1972). The Mountain People. New York: Simon and Schuster.

Turke, P. \& Betzig, L. (1985). Those who can do: Wealth, status, and reproductive success of Ifaluk. Ethology and Sociobiology, 6, 79-87.

Turke, P. \& Betzig, L. (1986). Food sharing on Ifaluk. Current Anthropology, 27, 397-400.

Turner, B. L. II. (1982). Pre-columbian agriculture: Review of Maya Subsistence. Science, $217,345-346$.

Vining, D. (1986). Social versus reproductive success: The central problem of human sociobiology. The Behavioral and Brain Sciences, 9, 167-216.

Voland, E. (1990). Differential reproductive success within the Krummhörn population (Germany, 18th and 19th centuries). Behav. Ecol. \& Sociobiol, 26, 65-72.

Walters, C. (1986). Adaptive management of renewable resources. New York: Macmillan Publishers.

Weick, K. E. (1984). Small wins: Redefining the scale of social problems. Amer. Psychol, $39(1), 40-49$.

Whyte, M. K. (1978). Cross-cultural codes dealing with the relative status of women. Ethnology, 17, 211-237.

Whyte, M. K. (1979). The status of women in pre-industrial society. Princeton: Princeton University Press. 
BOBBI S. LOW AND JOEL T. HEINEN

Williams, G. C. (1966). Adaptation and natural selection. Princeton: Princeton Univ. Press. Williams, G. C. (1989). A sociobiological expansion of evolution and ethics. In James Paradis \& George C. Williams. (Ed.). T. H. Huxley's evolution and ethics, with new essays on its Victorian and sociobiological context (pp 179-214). Princeton: Princeton University Press.

Wilson, E. O. (Ed.). (1988). Biodiversity. Washington, D.C: National Academy Press.

Wittenberger, J. F. (1981). Animal social behavior. Boston: Duxbury.

Woolfenden, G. E. \& Fitzpatrick, J. W. (1984). The Florida scrub jay: Demography of a cooperatively-breeding bird. Princeton: Princeton University Press.

Wynne-Edwards, V. C. (1962). Animal dispersion in relation to social behavior. Edinburgh: Oliver and Boyd.

Young, I. E. (1991). Reducing waste, saving materials. In L. R. Brown, (Ed.). State of the world 1991: A Worldwatch Institute report on progress for a sustainable society (pp. 39-55). New York: W.W. Norton and Co. 